\title{
GAMBARAN PERILAKU SADARI PADA WANITA USIA SUBUR DI UPT PUSKESMAS TEMBUKU I BANGLI
}

\section{BEHAVIORAL DESCRIPTION OF BREAST SELF- EXAMINATION ON WOMEN OF CHILDBEARING AGE AT PUBLIC HEALTH CENTER, TEMBUKU I BANGLI}

\author{
Ni Ketut Citrawati ${ }^{1}$, Ni Luh Putu Thrisna Dewi ${ }^{2}$ \\ Departemen Maternitas, Program Studi Ilmu Keperawatan, STIKes Wira Medika Bali ${ }^{1}$ \\ Departemen Keperawatan Medikal Bedah, Program Studi Ilmu Keperawatan, STIKes Wira \\ Medika Bali ${ }^{2}$
}

\begin{abstract}
ABSTRAK
Latar Belakang: Pemeriksaan payudara sendiri (SADARI) merupakan cara yang bisa dilakukan untuk mendeteksi kanker payudara. Sadari sangat penting karena 75-85\% keganasan ditemukan pada saat dilakukan sadari. Berdasarkan data rekapitulasi deteksi dini kanker payudara Dinas Kesehatan Provinsi Bali Tahun 2018 menunjukkan dari 39.157 wanita usia subur ditemukan 236 orang diantaranya memiliki benjolan atau tumor pada payudara, 44 orang dicurigai kanker dan 20 orang didiagnosa mengalami kanker payudara. Data kunjungan pemeriksaan kanker payudara dengan Clinical Breast Examination (CBE) menunjukkan data terendah pertama ditempati oleh lain Kabupaten Karangasem yaitu $1,15 \%$ dari 60.430 orang, peringkat kedua terendah berada di kabupaten Bangli yaitu 2,08\% dari 43.438 orang, dan kota Denpasar sebagai kabupaten/kota dengan jumlah perempuan usia subur 30-50 tahun terbanyak di Bali yaitu 115.143 orang mendapat angka kunjungan pemeriksaan kanker payudara terendah nomor tiga yaitu 2,46\%. Metode: Penelitian ini menggunakan design penelitian deskriptif kuantitatif dengan pendekatan crossectional. Hasil: Hasil Penelitian ini didapatkan karakteristik responden berdasarkan usia sebagian besar berada pada rentang 31-40 tahun, sebagian besar berpendidikan SMA, dan sebagian besar bekerja sebagai pedagang. Berdasarkan perilaku sadari sebagian besar responden memiliki perilaku baik dalam melakukan sadari yaitu 17 orang $(42,5 \%), 16$ orang $(40 \%)$ memiliki perilaku kurang terhadap sadari, dan sisanya 7 orang $(17,5 \%)$ memiliki perilaku sedang. Diskusi: Sadari merupakan salah satu cara mudah dan efisien untuk dapat mendeteksi kelainan payudara oleh diri sendiri. Sesuai dengan teori disebutkan bahwa tingginya angka kematian kanker payudara disebabkan oleh beberapa factor salah satunya adalah pengetahuan. Kesimpulan: Sebagian besar responden memiliki perilaku baik terhadap tindakan sadari.
\end{abstract}

Kata Kunci: Perilaku, Pemeriksaan Payudara Sendiri 


\begin{abstract}
Background: Breast self-examination (BSE) is one of many ways to detect breast cancer. It is very important because 75-85\% of malignancies are detected at the early time. Based on recapitulation data on early detection of breast cancer, the Bali Provincial Health Office in 2018 showed that out of 39,157 women of childbearing age, 236 of them had lumps or tumors in their breast, 44 people were suspected of having cancer and 20 people were diagnosed with breast cancer. Data on Clinical Breast Examination (CBE) shows that the lowest ranking is occupied by Karangasem Regency, namely 1.15\% of 60,430 people, the second lowest ranking is in Bangli Regency, which is 2.08\% of 43,438 people, and the third is Denpasar city as districts/cities with the highest number of women of childbearing age 30-50 years in Bali, namely 115,143 people, received the third lowest number of breast cancer screening visits, namely 2.46\%. Methods: This study uses a quantitative descriptive research design with a cross-sectional approach. Results: The results of this study found that the characteristics of respondents based on age were mostly in the range of 31-40 years old, most had high school education, and most worked as traders. Based on BSE behavior, most of the respondents have good behavior, 17 people (42.5\%), 16 people (40\%) have less behavior, and the remaining 7 people (17.5\%) have moderate behavior. Discussion: BSE is an easy and efficient way to detect breast abnormalities by yourself. In accordance with the theory, it is stated that the high mortality rate of breast cancer is caused by several factors, one of which is knowledge. Conclusion: Most of the respondents have good behavior towards BSE action.
\end{abstract}

Keyword: Breast self-examination, detect breast cancer, early detection of breast cancer

\begin{tabular}{ll}
\hline Alamat Korespondensi & : STIKes Wira Medika Bali \\
Email & : citrabali@ymail.com
\end{tabular}

\title{
PENDAHULUAN
}

Usia merupakan salah satu faktor yang membuat seseorang menjadi lebih berisiko untuk menderita penyakit kanker payudara. Prevalensi kasus kanker payudara di dunia terus mengalami peningkatan hingga mencapai 1.670 .000 kasus baru dan 522.000 kematian pada tahun 2012 (WHO, 2012). Tingginya angka kematian yang disumbangkan oleh kanker payudara di Indonesia, disebabkan karena lebih dari 80\% kasus kanker payudara ditemukan saat kanker sudah berada pada stadium yang lanjut, sehingga upaya pengobatan sulit dilakukan (Kemenkes, 2015). Pemeriksaan payudara sendiri (Sadari) adalah salah satu upaya deteksi dini atau metode skrining dalam upaya mendeteksi secara dini adanya tumor atau benjolan pada payudara.

Berdasarkan data rekapitulasi deteksi dini kanker payudara Dinas Kesehatan Provinsi Bali Tahun 2019 menunjukkan dari 39.157 wanita usia subur ditemukan 236 orang diantaranya memiliki benjolan atau tumor pada payudara, 44 orang dicurigai kanker dan 20 orang didiagnosa mengalami kanker payudara. Data kunjungan pemeriksaan kanker payudara dengan CBE menunjukkan data terendah pertama ditempati oleh lain Kabupaten Karangasem yaitu 1,15\% dari 60.430 orang, peringkat kedua terendah berada di kabupaten Bangli yaitu 2,08\% dari 43.438 orang, dan kota Denpasar sebagai kabupaten/kota dengan jumlah perempuan usia 
subur 30-50 tahun terbanyak di Bali yaitu 115.143 orang mendapat angka kunjungan pemeriksaan kanker payudara terendah nomor tiga yaitu 2,46\%. Tujuan

Penelitian bertujuan untuk mengetahui gambaran perilaku sadari pada wanita usia subur di UPT Puskesmas Tembuku I Bangli

\section{METODE PENELITIAN}

Lokasi Penelitian dilakukan di UPT Puskesmas Tembuku I Bangli, pada bulan Juni 2020. Penelitian ini menggunakan penelitian deskriptif kuantitatif dengan pendekatan cross sectional. Populasi dalam penelitian ini adalah seluruh wanita usia subur yang datang ke puskesmas, sedangkan pengambilan sampel menggunakan probability dengan tehnik total sampling sebanyak 40 WUS. Proses pengumpulan data dengan menggunakan Alat pengumpul data yaitu kuesioner perilaku. Pengolahan data penelitian dilakukan dengan cara editing, coding, entry dan tabulating dengan menggunakan program komputer. Analisa data yang digunakan analisa univariat yaitu distribusi frekuensi.

\section{HASIL DAN PEMBAHASAN}

\section{HASIL PENELITIAN}

a. Kharakteristik Responden

Tabel 1

Distribusi Frekuensi kharakteristik Umur, Pendidikan,Pekerjaan

\begin{tabular}{ccc}
\hline Karakteristik & $\mathrm{f}$ & $\%$ \\
\hline Umur & & \\
$20-30$ th & 21 & 52.5 \\
$31-40$ th & 19 & 47.5 \\
Total & 40 & 100 \\
& & \\
\hline Total & $\mathbf{5 0 0}$ & $\mathbf{1 0 0 . 0 0}$ \\
\hline
\end{tabular}

\begin{tabular}{lcc}
\hline Pendidikan & & \\
Sd & 12 & 30 \\
SMP & 11 & 27.5 \\
SMA & 16 & 40 \\
PT & 1 & 2.5 \\
\hline Total & $\mathbf{4 0}$ & $\mathbf{1 0 0}$ \\
\hline
\end{tabular}




\begin{tabular}{lcr}
\hline Pekerjaan & & \\
PNS & 1 & 2.5 \\
Wiraswasta & 17 & 42.5 \\
Pedagang & 22 & 55.0 \\
& & \\
\hline Total & $\mathbf{4 0}$ & $\mathbf{1 0 0}$ \\
\hline
\end{tabular}

\section{b. Gambaran Perilaku Sadari}

Tabel 2

Distribusi Frekuensi Gambaran Perilaku Sadari

\begin{tabular}{lcc}
\hline \multicolumn{1}{c}{ Perilaku Sadari } & f & $\%$ \\
\hline Perilaku Sadari baik & 17 & 42.55 \\
Perilaku sadari Cukup & 7 & 17.55 \\
Perilaku Sadari Kurang & 16 & 40 \\
& & \\
\hline Total & $\mathbf{4 0}$ & $\mathbf{1 0 0}$ \\
\hline
\end{tabular}

\section{PEMBAHASAN}

\section{a. Gambaran Umum Responden}

Dalam penelitian ini diperoleh sebagian besar responden berusia 2030 tahun, sebanyak 21 orang (52,5\%). Kanker payudara dialami oleh perempuan dengan usia 20 tahun atau lebih, ini berarti tidak ada kata terlalu dini untuk memberikan pendidikan sadari. Pada wanita muda masih sulit untuk melakukan deteksi kanker payudara dengan sadari karena payudara mereka masih berserabut, sehingga dianjurkan sebaiknya mereka mulai mendeteksi kanker payudara dengan sadari pada usia 20 tahun karena pada umumnya usia tersebut jaringan pada wanita sudah terbentuk sempurna. Karakteristik responden yang dilihat dari tingkat pendidikan pada penelitian ini sebagian besar adalah pendidikan SMA, Pendidikan akan membuat seseorang ingin tahu, mencari pengalaman dan memahami suatu informasi dengan baik sehingga informasi yang diterima akan menjadi pengetahuan yang baik (Azwar, 2007).

Karakteristik responden berdasarkan pekerjaan sebagian besar bekerja sebagai pedagang. Hal ini sesuai dengan pendapat Mubarak (2009) yang menyatakan bahwa lingkungan pekerjaan dapat menjadikan seseorang memperoleh pengalaman dan pengetahuan baik secara langsung maupun tidak langsung. Orang yang jenis pekerjaannya Orang yang jenis pekerjaannya cenderung mudah mendapatkan informasi tingkat pengetahuannya akan lebih tinggi dibandingkan dengan orang yang tidak bekerja. 


\section{b. Gambaran Perilaku Sadari}

Berdasarkan hasil penelitian didapatkan bahwa gambaran perilaku sadari pada wanita usia subur diperoleh hasil sebagian besar responden mempunyai prilaku baik sebanyak 17 orang (42,55\%). Hal ini sejalan dengan penelitian yang dilakukan Defirna, 2015 yang menunjukkan bahwa sebagian besar mahasiswi rutin melakukan pemeriksaan rutin sadari sebanyak 35 responden, (38\%), berbeda dengan penelitian yang dilakukan Keren (2017) tentang Gambaran Tingkat pengetahuan dan Perilaku tentang Pemeriksaan Payudara Sadari (Sadari) Pada remaja putri di wilayah kerja UPT Puskesmas Blahbatuh II Gianyar Bali Indonesia diperoleh hasil bahwa sebagian responden memiliki perilaku rendah tentang pemeriksaan sadari yaitu 28 orang $(96,6 \%)$.

Pada hasil penelitian dijelaskan bahwa tingginya kesadaran WUS dalam melakukan pemeriksaan sadari sudah baik, lingkungan pekerjaan dapat menjadikan seseorang memperoleh pengalaman dan pengetahuan baik secara langsung maupun tidak langsung. Pemeriksaan payudara sendiri sangat penting untuk dilakukan karena hampir $85 \%$ benjolan di payudara ditemukan oleh penderita sendiri. Disamping itu pemeriksaan payudara sendiri yang dilaksanakan setiap satu bulan sekali menjadi metode yang paling murah dan sederhana yang dapat dilakukan secara mandiri oleh wanita dibandingkan dengan momografi.

\section{SIMPULAN DAN SARAN}

Simpulan: berdasarkan hasil penelitian diperoleh hasil bahwa usia responden sebagian besar berada pada usia 20-30 tahun sebanyak 21 orang(52.5\%). Sebagian besar responden memiliki pendidikan SMA sebanyak 16 orang $(40 \%)$ dan sebagian besar responden memiliki pekerjaan sebagai pedagang sebanyak 22 orang ( 55.,5\%). Saran: peran serta lingkungan diharapkan sebagai salah satu cara meningkatkan pengetahuan WUS mengenai sadari melalui penyuluhan. Peran tenaga kesehatan setempat juga berperan penting sebagai pendampingan dalam melakukan sadari untuk meningkatkan perilaku sadari.

\section{DAFTAR PUSTAKA}

Azwar, Saifuddin. 2007. Metode Penelitian. Pustaka Pelajar: Yogyakarta.

Dinas Kesehatan Provinsi Bali. Profil Kesehatan Provinsi Bali. Dinas kesehatan

Provinsi Bali; 2019. 25-27 p.

Defirna, I.P. 2015. Gambaran Perilaku Pemeriksaan Payudara Sendiri (sadari) pada Mahasiswi Fakultas Kedokteran dan Ilmu Kesehatan UIN syarif Hidayatullah Jakarta.diakses melalui http://repository.uinjkt.ac.id. 5 desember 2020

Keren, K. S., Wirakusuma,I.B. 2017. Gambaran Tingkat pengetahuan dan Perilaku tentang Pemeriksaan Payudara Sadari (Sadari) Pada remaja putri di wilayah 
kerja UPT Puskesmas Blahbatuh II Gianyar Bali Indonesia: DOAJ Directory Of Open access Journals, Intisari Sains Medis 2017,Volume 8,Number 3:184-188

Kemenkes RI. Profil Kesehatan Indonesia. Kementrian Kesehatan Republik Indonesia; 2015.

Mubarak \& Chayatin. (2009). Pendidikan Kesehatan, Jakarta: EGC. 